EGU2020-22061, updated on 06 May 2020

https://doi.org/10.5194/egusphere-egu2020-22061

EGU General Assembly 2020

(c) Author(s) 2020. This work is distributed under

the Creative Commons Attribution 4.0 License.

\title{
Flood-based Farming as Affected by Hydrological Deficit in the Semiarid Lowlands of Northern Ethiopia
}

\author{
Emnet Negash ${ }^{1}$, Jan Nyssen ${ }^{2}$, Girmay Gebresamuel ${ }^{3}$, Tesfa-alem Embaye ${ }^{4}$, Alick Nguvulu ${ }^{5}$, \\ Hailemariam Meaza ${ }^{6}$, Misgina Gebrehiwot ${ }^{6}$, Biadglign Demisse ${ }^{6,7}$, Tesfaalem Gebreyohannes $^{6}$, and \\ Amanuel Zenebe ${ }^{3}$ \\ ${ }^{1}$ Institute of Climate and Society, Mekelle University, Mekelle, Ethiopia (emnet.negash@mu.edu.et) \\ ${ }^{2}$ Department of Geography, Ghent University, Gent, Belgium \\ ${ }^{3}$ Department of Land Resource Management and Environmental Protection, Mekelle University, Mekelle, Ethiopia \\ ${ }^{4}$ Institute of Water and Environment, Mekelle University, Mekelle, Ethiopia \\ ${ }^{5}$ Department of Geomatics Engineering, Copperbelt University, Kitwe, Zambia \\ ${ }^{6}$ Department of Geography and Environmental Studies, Mekelle University, Mekelle, Ethiopia \\ ${ }^{7}$ Institute of Geo-information and Earth Observation Science, Mekelle University, Mekelle, Ethiopia
}

Agriculture remains the dominant source of food production and the livelihood foundation for majority of the rural poor in the sub-Saharan Africa, including Ethiopia. Access to agriculturalwater is, however, a limitation hindering crop productivity and end food insecurity in the drylands. In rain-deficit lowlands such as in the Raya-valley, flood-based farming is a means of improving crop production. Such spate irrigation systems grow in importance; though the effects of headwater hydrological deficit on flood-farming systems are lacking evidence. The present work investigates the impacts of headwater hydrological deficit on spate-irrigated agriculture in Tsge'a spate systems. Canal length and area of spate-irrigated agriculture along Guguf river for the $1980 \mathrm{~s}$ and 2010s were tracked using Global Positioning System; while runoff trend analysed using linear regression. Annual volume of flash-flood shrunk by $7.36 \times 10^{6} \mathrm{~m}^{3}$. This is mainly due to changing climate and increasing water retention by the soil and humans at the escarpment. As a result, length of canals and area of spate-based farms downstream declined by $1.37 \mathrm{~km} \mathrm{(35 \% )}$ and 1540 ha (57.5\%), respectively, only in three decades time. This corresponds to an average withdrawal of -44 ha $\mathrm{yr}^{-1}$. A $1 \times 10^{6} \mathrm{~m}^{3}$ decline in flash-flood caused a 366.4 ha decline in spate-based farms. Moreover, farm fields located next to the river course are less affected, as compared to farms on the tail of the scheme. If the current trend continues, there is likely a high risk that the remaining farms currently receiving flood may run out of spate systems. Therefore, flood management technologies are needed to optimize the efficiency of soil moisture in the spate system.

The abstract is based on Negash, E., Gebresamuel, G., Embaye, T., Nguvulu, A., Meaza, H., Gebrehiwot, M., Demisse, B., Gebreyohannes, T., Nyssen, J., \& Zenebe, A. (2020). Impact of headwater hydrological deficit on the downstream flood-based farming system in northern Ethiopia. Irrigation and Drainage, In Press. 